УДК:351

DOI: https://doi.org/10.32689/2618-0065-2019-2/1-107-115

Романенко Євген Олександрович, доктор наук з державного управління, професор, Заслужений юрист України, Проректор Міжрегіональної Академії управління персоналом, 03039, м. Київ, вул. Фрометівська, 2, тел.: (044) 264-52-54, e-mail: poboss1978@gmail.com.

ORCID: 0000-0003-2285-0543

Пономаренко Тетяна Вадимівна, студентка Міжрегіональної академії управління персоналом, 03039, вул. Фрометівська, 2, тел.: 0935004890; e-mail: ponomarenko1592@gmail.com

ORCID: 0000-0001-5395-5618

\title{
УПРАВЛІНСЬКА ДІЯЛЬНІСТЬ У ЗАГАЛЬНООСВІТНЬОМУ НАВЧАЛЬНОМУ ЗАКЛАДІ
}

Анотація. Стаття присвячена розгляду управлінської діяльності у загальноосвітньому навчальному закладі. Розглянута управлінська діяльність, а також підходи до побудови структури управління навчальним закладом. Розглянута модель навчального закладу та його ланки в адмініструванні управлінні. Проаналізовано методологічні засади управління навчальним закладом та їх реалізацію у сьогоденні. Розглянуто проблеми управлінської діяльності навчальних закладів. Визначено управлінські технології, які корегують роботу адміністрації. Змодельована соціальнопедагогічна система управління навчальним закладом. Доведено, що управління загальноосвітніми навчальними закладами базується на положеннях теорії управління. Головними складовими іiі є певні тенденції, відповідні їм закономірності й, пов'язані 3 ними, принципи управління загальноосвітніми навчальними закладами. Здійснення управління відповідно до вимог, що випливають із розроблених закономірностей i принципів, цілком залежить від управлінської діяльності керівників навчальних закладів.

Обгрунтовано, що тенденції розвитку управління навчальними закладами визначаються розвитком i функціонуванням державного управління, соціальними та економічними процесами в суспільстві. Але головним фактором, що впливає на управлінські процеси в навчальних закладах, є система освіти України, яка віддзеркалює всі явища, що відбуваються у державі та за їі межами.

Визначено, що управління є тією рушійною силою, яка націлена на активізацію людини через створення оптимальних умов для прояву та розвитку їі творчого потенціалу. Тому керівникам закладів освіти слід орієнтуватися в різноманітності сучасних управлінських ідей, вивчати й 
успішно застосовувати досягнення науки та перспективного педагогічного досвіду, організовувати творчу діяльність.

Ключові слова: навчальний заклад, управління, управління навчальним закладом, освітня організація, організаційна структура, об'єкт управління, соціально-педагогічні системи, навчально-виховний процес, соціально-педагогічна система.

Romanenko Yevhen Oleksandrovych, Doctor of Science in Public Administration, Professor, Honored Lawyer of Ukraine, vice-rector, Interregional Academy of Personnel Management, 03039, Kyiv, Str. Frometivska, 2, tel.: (044) 264-52-54, e-mail: poboss1978@gmail.com

ORCID: 0000-0003-2285-0543

Ponomarenko Tatiana Vadimovna, student, Interregional Academy of Personnel Management, 03039, st. Frometivska, 2, tel .: 0935004890; email: ponomarenko1592@gmail.com

ORCID: 0000-0001-5395-5618

\title{
MANAGEMENT ACTIVITIES IN GENERAL EDUCATIONAL INSTITUTION
}

\begin{abstract}
The article is devoted to consideration of management activity in a general educational institution. Management activity is considered, as well as approaches to the construction of the management structure of an educational institution. The model of an educational institution and its links in administration and management is considered. The methodological principles of management of educational institution and its realization in the present are analyzed. The problems of administrative activity of educational institutions are considered. The managerial technologies that regulate the work of the administration are determined. Simulated socio-pedagogical system of management of an educational institution. It is proved that the management of general educational institutions is based on the provisions of the theory of management. Its main components are certain tendencies, corresponding to their regularities and, related to them, the principles of management of general educational institutions. The management in accordance with the requirements arising from the developed laws and principles, entirely depends on the management activities of the heads of educational institutions.

It is substantiated that trends in the development of management of educational institutions are determined by the development and functioning of public administration, social and economic processes in society. But the main factor influencing the management processes in educational institutions is the
\end{abstract}


education system of Ukraine, which reflects all the phenomena occurring in the state and beyond its borders.

It is determined that management is the driving force that aims at activating a person through the creation of optimal conditions for the manifestation and development of his creative potential. Therefore, heads of educational institutions should be guided by the diversity of modern managerial ideas, study and successfully apply the achievements of science and perspective pedagogical experience, organize creative activity.

Key words: educational institution, management, management of educational institution, educational organization, organizational structure, object of management, social-pedagogical systems, educational process, social-pedagogical system.

Постановка проблеми. Актуальність теми зумовлена необхідністю подальшого розвитку теорії та практики управління соціально-педагогічними системами в інформаційному суспільстві в контексті завдань, які висувають перед системою освіти, i, зокрема, загальною середньою освітою, Закони України «Про освіту», «Про загальну середню освіту», Національна доктрина розвитку освіти тощо.

На сучасному етапі розвитку загальної середньої освіти в Україні особливої ваги набирає проблема взаємовідповідності змін у навчальновиховному процесі та системі управління загальноосвітніх навчальних закладів (ЗНЗ). Поява загальноосвітніх навчальних закладів різних типів, змістовна робота щодо запровадження особистісно орієнтованого навчання, організація профільного навчання, умови зовнішнього незалежного оцінювання тощо потребують конструювання ефективних систем управління із застосуванням технологій, адекватних процесам, що відбуваються в освіті.

Аналіз останніх публікацій за проблематикою.Проблема управління

ЗНЗ грунтовно розглянута в роботах Ю. К. Бабанського, С. С. Березняка, В. І. Бондаря, Л. І. Даниленко, Г. В. Сльникової, Ю. А. Конаржевського, В. І. Маслова, В. С. Пікельної, М. Л. Портнова, М. М. Поташника, П. І. Третьякова та ін.

Управління загальноосвітнім навчальним закладом вони розглядають як цілеспрямовану узгоджену взаємодоповнюючу систему дій керуючої i керованої підсистем для досягнення поставленої мети.

Управління загальноосвітнім навчальним закладом (ЗН3), з точки зору теорії систем, - це технологічний процес впливу на цілісну, відкриту, динамічну соціально-педагогічну систему.

Технологізація всіх аспектів розвитку соціальних систем (в тому числі й освітніх) $€$ характерною ознакою нашого часу (В. М. Іванов, В. I. Подшивалкіна, А. А. Шиян). Спочатку це проявилося в розробці технологій навчання (В. П. Беспалько, Л. В. Буркова, Ю. В. Васьков, В. В. Гузєєв, М. П. Капустін, О. М. Пєхота, Г. К. Селевко та ін.), але згодом стало очевидним і 
для систем управління (В. В. Гуменюк, Г. В. Єльникова, А. М. Єрмола, Г. Ю. Капто, В. С. Лазарєв, О. М. Мойсєєв, В. П. Сімонов). Таким чином, сучасні технології навчання сьогодні грунтовно розроблені, Проте цього не можна сказати про технології управління, особливо на рівні ЗНЗ.

Разом 3 тим, аналіз сучасного стану функціонування ЗНЗ та використання у практиці управлінських технологій дозволив конкретизувати протиріччя між:

1. сучасними вимогами до функціонування та розвитку ЗНЗ i технологіями управління, які використовуються керівниками закладів освіти;

2. темпами розвитку керуючої та керованої підсистем 3НЗ;

3. реальними станом управління ЗНЗ і рівнем умінь і навичок суб'єктів управління щодо використання управлінських технологій в своїй діяльності;

4. рівнем компетентності керівників ЗНЗ та необхідністю прийняття управлінських рішень в умовах нестабільності і мінливості ситуацій.

Таким чином, відставання у розвитку керуючої системи у порівнянні 3 керованою обумовило тему нашої статті «Управлінська діяльність у загальноосвітньому навчальному закладі». У зв'язку 3 цим питання управління освітніми процесами $є$ актуальним, оскільки шкільна практика свідчить про недостатню підготовленість керівників шкіл до професійної управлінської діяльності.

Формулювання цілей (мети) статті. Здійснення аналізу управлінської діяльності у загальноосвітньому навчальному закладі 3 метою іiі адаптації до суспільно-політичних реалій України.

Виклад основного матеріалу. Сучасне управління у сфері загальної середньої освіти базується на положеннях освітнього менеджменту методологічної складовою якого є загальні положення теорії управління (М. Альберт, С. О’Доннел, В. Кінг, Д. Кліланд, Г. Кунц, А. Маслоу, М. Х. Мескон, Ф. Тейлор, С. Л. Оптнер, У. Оучи, А. Файоль, М. П. Фоллет, Ф. Хедоурі та ін.); сучасні дослідження 3 питань філософії освіти (Л. С. Горбунова, С. Ф. Клепко, Л. А. Лавринович, В. С. Лутай, С. І. Подмазін, В. М. Шепель, Л. П. Сніцар); теоретичні наробки з питань управління ЗНЗ (В. І. Бондар, Ю. В. Васильєв, Л. І. Даниленко, Г. В. Сльникова, Г. Ю. Капто,

В. І. Маслов, О. М. Мойсєєв, Н. М. Островерхова, В. С. Пікельна, М. М. Поташник, В. П. Сімонов, П. І. Третьяков, Т. І. Шамова та ін.); теорія і методика моделювання управлінської діяльності (О. М. Мойсєєв, В. С. Пікельна, О. Г. Хомерики та ін.). На цій підставі загальноосвітній навчальний заклад розглядається як система, для якої характерні всі ознаки і властивості відкритої соціальної системи i необхідним $є$ застосування системного підходу [1].

Отже, загальноосвітній навчальний заклад - це відкрита соціальнопедагогічна система, яка регулює свої відносини з зовнішнім середовищем на 
підставі взаємодії з ним. Використання системного підходу є необхідною умовою функціонування і розвитку такої системи.

Для того, щоб усвідомити, як системний підхід допомагає керівнику загальноосвітнього закладу краще зрозуміти цей заклад і більш ефективно здійснювати управління, слід зазначити, насамперед, що система - це певна цілісність, що складається із взаємопов'язаних частин, кожна 3 яких долучає свій внесок до характеристик цілого.

Існує два основних типи систем: закриті й відкриті. Закрита система має жорсткі фіксовані межі, iї дії перебувають у відносній незалежності від середовища, яке цю систему оточує. Вона діє за аналогією до годинника, взаємопов'язані частини якого рухаються безперервно і точно, якщо годинник заведено або в нього поставлено батарейку. I поки у годиннику $\epsilon$ джерело накопиченої енергії, його система незалежна від оточуючого середовища[2].

Усі загальноосвітні навчальні заклади є відкритими системами. Вони, як ми вже зазначали, характеризуються взаємодією із зовнішнім середовищем. Виживання будь-якого навчального закладу залежить від зовнішнього світу.

Тому зовнішнє середовище $\epsilon$ важливою змінною в функціонуванні i управлінні ЗНЗ (рис. 1.).

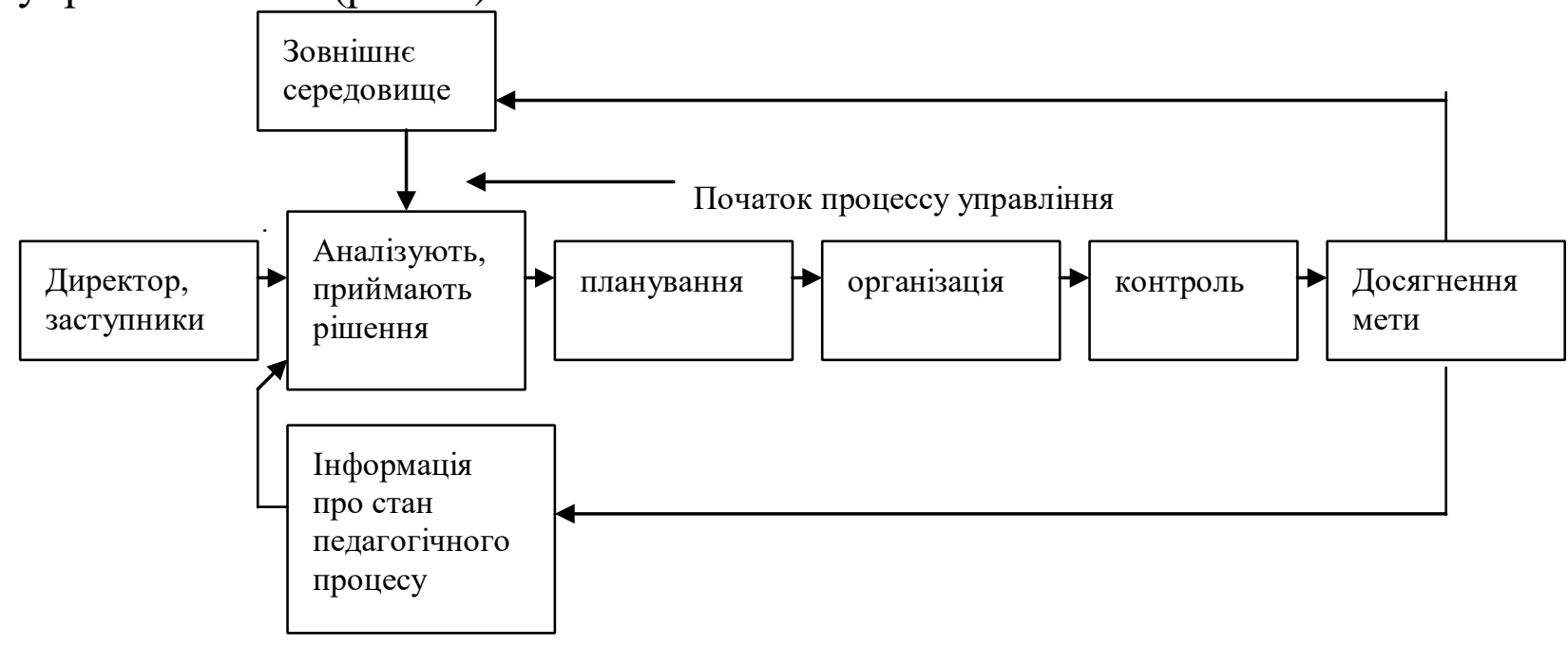

Рис. 1. Процес управління ЗНЗ з точки зору відкритої системи

Зовнішне середовище загальноосвітнього навчального закладу визначається як сукупність факторів i множинність елементів, що опосередковано або безпосередньо впливають на його діяльність. До них віднесено: економіку, соціальне середовище, політику, ринок, технології, екологію, міжнаціональні зв'язки. Метою аналізу зовнішнього середовища загальноосвітнього навчального закладу має бути характеристика його впливу на загальноосвітній навчальний заклад [3]. 
Функціонування загальноосвітнього навчального закладу як соціально-педагогічної системи спрямоване на досягнення мети, зумовленої потребами особистості й суспільства. Вона повинна бути досягнута в суворо визначений час (9-11 років). Мета закладу визначає зміст педагогічної системи, який, у свою чергу, передбачає різноманітність форм і методів його реалізації. Рівень досягнутих результатів характеризує дієвість і результативність системи.

Тому фактори цілей і результатів є системоутворюючими факторами педагогічної системи.

В управлінні школою $є$ два типи завдань. Перші пов'язані зі стабілізацією наявної системи роботи навчального закладу. Таких завдань багато: забезпечення чистоти і порядку у навчальному закладі, своєчасна заміна педагогів, які захворіли, організація контролю за виконанням нормативних вимог до документації, до виконання навчальних програм, правил техніки безпеки тощо. Ці завдання повторюються з року в рік.

Інші завдання пов'язані 3 розвитком наявної системи роботи. Вони виникають тоді, коли необхідно змінити зміст навчання, використовувати нові технології організації навчально-виховного процесу, змінити тип навчального закладу.

Управління як невід'ємна частина педагогічної системи навчального закладу, іiі системоутворююча засада, має об'єктивну природу, але за механізмом реалізації - це суб'єктивний процес. Воно може бути переважно інтуїтивним або спиратися на теоретичні основи науки. У зв'язку з цим надзвичайно важливо визначити, як співвідносяться практика i теорія управління.

В Україні вивченням проблеми управління навчальним закладом займаються вчені Л. І. Даниленко, Г. А. Дмитренко, Г. В. Сльнікова, О. І. Мармаза, Є. М. Павлютенков, В. В. Крижко, С. М. Хриков та ін. Однак, констатують, що розробка проблеми управління навчальним закладом знаходиться на початковій стадії [4].

Особливістю розвитку теорії управління освітніми системами в зарубіжних країнах стала іiі опора на різноманітні соціальні, педагогічні, психологічні теорії. Це привело до концептуалізації розвитку теорії управління освітніми установами, що, безсумнівно, можна вважати головною iї особливістю.

Концептуалізація теорії управління навчальним закладом не стала особливістю вітчизняної науки. Це пов’язано 3 тим, що наші вчені цілком орієнтувалися на положення загальної теорії управління і теорії соціального управління. Фактично сутність багатьох школознавчих робіт полягала у перенесенні загальних положень теорії управління на освітнє підгрунтя. При цьому особливості навчальних закладів враховувалися переважно на технологічному, а не на концептуальному рівні. 
Розгляд управління загальноосвітнім навчальним закладом 3 точки зору структури управління дозволяє констатувати, що у взаємопов’язаній мережі позицій - керуюча підсистема - керована підсистема, вирішальна роль належить управляючій підсистемі. Структура цієї підсистеми більшості загальноосвітніх навчальних закладів має чотири рівні управління [5-14].

Перший рівень: директор школи, призначений державним органом чи обраний колективом; керівники ради школи, учнівського комітету, громадських об'єднань. Цей рівень визначає стратегічні напрями розвитку школи.

Другий рівень: заступники директора школи, соціальний педагог, шкільний психолог, відповідальний за організацію суспільно корисної праці, старші вожаті, помічник директора школи з господарської частини, а також органи та об'єднання, які беруть участь у самоуправлінні.

Третій рівень: учителі, вихователі, класні керівники, що виконують управлінські функції стосовно учнів і батьків, дитячих об'єднань, гуртків у системі позакласної роботи.

Четвертий рівень: органи класного і загальношкільного учнівського самоуправління. Цей рівень свідчить про суб'єкт-суб'єктний характер стосунків між педагогами і учнями.

У цій ієрархічній схемі кожен вищезазначений рівень суб'єкта управління слугує водночас об'єктом управління відносно тих рівнів, що знаходяться вище.

У підсистемі, шо управляється, основне місце належить учнівському колективу. В ньому також виділяють два рівні управління по вертикалі: загальношкільний колектив i класні колективи. По горизонталі керована підсистема представлена учнівськими громадськими організаціями, творчими об'єднаннями, гуртками, клубами, спортивними секціями i подальша керована підсистема відображає різноманітність і єдність видів учнівської діяльності (навчальної, дослідницької, суспільно корисної, художньої, спортивної).

Висновки і перспективи подальших досліджень. Усе зазначене підводить до висновку про необхідність розробки концепції управління загальноосвітнім навчальним закладом, яка б найбільш повно відображала сутність цього явища i найбільш природно синтезувала в собі досягнення вітчизняної і зарубіжної теорії і практики управління.

Загальноосвітній навчальний заклад як об'єкт управління є складною відкритою соціально-педагогічною системою, яка регулює свою діяльність із зовнішнім середовищем. На підставі його аналізу визначає мету свого існування. Фактори цілей і результатів є системоутворюючими факторами педагогічної системи що допомагає сконцентрувати увагу керівників загальноосвітнього навчального закладу, учителів, учнів на визначення цілей i способів досягнення результату, на створення умов належного 
функціонування педагогічного процесу, відбір змісту i використання різноманітних форм, методів і засобів навчально-виховної роботи.

Функціональні компоненти управлінського циклу представлені: аналізом, плануванням, організацією, контролем. У цьому випадку управління педагогічною системою дозволяє зберегти іï цілісність і одночасно змінювати, впливати на дію ії окремих компонентів.

\section{Jimepamypa:}

1. Паращенко, Л. Проблеми державно-громадського управління загальною середньою освітою в Україні / Л. Паращенко // Освіта і управління. - 2010.- № 4. - С. 3240. - Бібліогр.: 21 назв.- укр.

2. Вологін, Ю. Менеджмент в освіті як соціально-психологічне визначення особистості в українській діяльності / Ю. Вологін // Молодь і ринок. - 2011.- № 9- С. 114-118. - Бібліогр.: 18 назв.- укр.

3. Барліт, О. О. Основи стратегічного менеджменту в освіті: навч.

посіб. / О. О. Барліт, М. В. Елькін, М. М. Окса. — Мелітополь: ММД, 2009.

- 256 с. - укр.

4. Андрущенко, В. П. Державно-громадський характер управління освітою / В Андрущенко // Вища освіта України 2011.- № 3.- С. 5-8 .- Бібліогр.: 3 назв.- укр.

5. Калініна, Л. Автоматизована система управління -школаl: моделювання і технологія використання / Л. Калініна // Освіта і управління. - 2006.- № 1.- С. 61-70. Бібліогр.: 5 назв. - укр.

6. Артюх, М. Особливості сучасного оновлення управління діяльністю районного відділу освіти / М. Артюх // Освіта і управління. - 2006. - № 2. - С. 55-58. - Бібліогр.: 3 назв.- укр.

7. Болонський процес: проблеми, пошуки, перспективи: Матеріали конф., Суми, 21 - 22 берез. 2006 р. / Сум. держ. пед. ун-т ім. А.С.Макаренка / Ред.: О. Г. Козлова. - Суми: Унів. кн., 2006. - 214 с. - укр.

8. Величко О. Сучасний менеджмент якості науково-педагогічних працівників вищого навчального закладу / О. Величко, В. Іващенко, О. Ясев, О. Рожков // Вища школа. - 2006.- № 5-6. - С. 34-39. - Бібліогр.: 2 назв.- укр.

9. Данилова, Г. Акмеологія управління: інноваційні технології вдосконалення професіоналізму керівних кадрів / Г. Данилова // Освіта і управління. - 2011. - № 1. - С. 31-42. - Бібліогр.: 20 назв - укр.

10. Інноваційний менеджмент: проблеми формування в умовах перехідної економіки / Міжрегіон. акад. упр. персоналом / Ред. М.Ф. Головатий. - К., 2002. — 400 с. — (Наук. пр. МАУП; Вип. 3). — укр.

11. Мармаза О. I. Проектний підхід до управління навчальним закладом / O. I. Мармаза. - Х.: Основа, 2003. - 79 с.- Бібліогр.: 31 назв. - укр.

12. Нікітенко, Р. І. До питання про соціально-психологічний портрет керівника позашкільного закладу / Р. І. Нікітенко // Наша школа.- N4.- 2012.

- С. 59-60. - Бібліогр.: 10 назв. - укр.

13. Хриков Е.Н. Теория и практика внутришкольного управлення/ Хриков Е.Н. - Луганск, 1997. - 118 с.

14. Шульга, Л. Сучасний погляд на управління загальноосвітнім навчальним закладом / Л. Шульга // Освіта і управління. - 2006. - № 3-4. - С. 138-143.- Бібліогр.: 22 назв. - укр. 


\section{Reference:}

1. Parashchenko, L. (2010). Problemy derzhavno-hromadskoho upravlinnia zahalnoiu serednoiu osvitoiu v Ukraini [Problems of State-Public Management of General Secondary Education in Ukraine]. Osvita i upravlinnia - Education and Management, 4, 32-40 [in Ukrainian].

2. Volohin, Yu. (2011). Menedzhment v osviti yak sotsialno-psykholohichne vyznachennia osobystosti $\mathrm{v}$ ukrainskii diialnosti [Management in education as a sociopsychological definition of personality in Ukrainian activity]. Molod i rynok - Youth and Market, 9, 114-118 [in Ukrainian].

3. Barlit, O. O., Elkin, M. V., Oksa, M. M. (2009). Osnovy stratehichnoho menedzhmentu $v$ [Fundamentals of Strategic Management in Education]. Melitopol: MMD [in Ukrainian].

4. Andrushchenko, V. P. (2011). Derzhavno-hromadskyi kharakter upravlinnia osvitoiu [State-public nature of education management]. Vyshcha osvita Ukrainy - Higher education in Ukraine, 3, 5-8 [in Ukrainian].

5. Kalinina, L. (2006). Avtomatyzovana systema upravlinnia -shkola: modeliuvannia i tekhnolohiia vykorystannia [The automated control system - the school: modeling and technology of use]. Osvita i upravlinnia - Education and management, 1, 61-70 [in Ukrainian].

6. Artiukh, M. (2006). Osoblyvosti suchasnoho onovlennia upravlinnia diialnistiu raionnoho viddilu osvity [Features of modern upgrade management activity of district department of education]. Osvita i upravlinnia - Education and management, 2, 55-58 [in Ukrainian].

7. Kozlova, O. H. (Eds.). (2006). Bolonskyi protses: problemy, poshuky, perspektyvy - Bologna process: problems, searches, perspectives: Proceedings of the conference. Sumy: Sum. derzh. ped. un-t im. A.S.Makarenka [in Ukrainian].

8. Velychko, O., Ivashchenko, V., Yasev, O., Rozhkov, O. (2006). Suchasnyi menedzhment yakosti naukovo-pedahohichnykh pratsivnykiv vyshchoho navchalnoho zakladu [Modern quality management of scientific and pedagogical workers of a higher educational institution]. Vyshcha shkola - Higher school, 5-6, 34-39 [in Ukrainian].

9. Danylova, H. (2011). Akmeolohiia upravlinnia: innovatsiini tekhnolohii vdoskonalennia profesionalizmu kerivnykh kadriv [Management acmecology: innovative technologies for improving the professionalism of management personnel]. Osvita i upravlinnia - Education and Management, 1, 31-42 [in Ukrainian].

10. Holovatyi, M. F. (Eds.). (2002). Innovatsiinyi menedzhment: problemy formuvannia $v$ umovakh perekhidnoi ekonomiky [Innovative Management: Problems of Formation in a Transitional Economy]. Kyiv: MAUP [in Ukrainian].

11. Marmaza, O. I. (2003). Proektnyi pidkhid do upravlinnia navchalnym zakladom [Project Approach to Management of Educational Institution]. Kharkiv: Osnova [in Ukrainian].

12. Nikitenko, R. I. (2012). Do pytannia pro sotsialno-psykholohichnyi portret kerivnyka pozashkilnoho zakladu [On the question of the socio-psychological portrait of the head of an out-of-school institution]. Nasha shkola - Our school, 4, 59-60 [in Ukrainian].

13. Khrykov, E. N. (1997). Teoryia y praktyka vnutryshkolnoho upravlennia [Theory and practice of intracooling management]. Luhansk [in Ukrainian].

14. Shulha, L. (2006). Suchasnyi pohliad na upravlinnia zahalnoosvitnim navchalnym zakladom [Modern view on the management of a general educational institution]. Osvita $i$ upravlinnia - Education and Management, 3-4, 138-143 [in Ukrainian]. 